\title{
Kemampuan Guru PAUD dalam Mengelola Pembelajaran pada Masa Pandemi Covid-19
}

\section{A. Sintya Inneke Putri ${ }^{1}$}

${ }^{1}$ Pendidikan Dasar, Universitas Pendidikan Ganesha, Singaraja, Indonesia

\section{ARTICLE INFO}

Article history:

Received 22 Januari 2021

Revised 11 Februari 2021

Accepted 06 Maret 2021

Available online 25 April 2021

Kata Kunci:

Kendala, Kemampuan, Solusi,

Pembelajaran Daring

Keywords:

Obstacles, Ability, Solution,

Online Learning

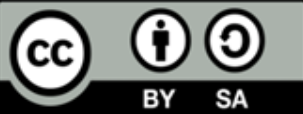

This is an open access article under the CCBY-SA license.

Copyright $@$ Universitas Pendidikan Ganesha. All rights reserved.

\begin{abstract}
A B S T R A K
Dalam Pembelajaran daring pada masa pandemi covid-19 guru dihadapi oleh suatu kendala atas perubahan dunia pendidikan khususnya pada pendidikan anak usia dini, sehingga dari kendala tersebut guru dituntut untuk memiliki kemampuan dalam mengelola pembelajaran. Penelitian ini bertujuan untuk mengetahui dan mengukur kemampuan guru dalam mengelola pelaksanaan pembelajaran daring pada masa pandemi covid19. Jenis penelitian ini adalah survei deskriptif dengan subjek yang diteliti adalah guru PAUD. Dalam pengambilan sampel menggunakan teknik Proportional Random Sampling dengan cara perhitungan statistik yaitu dengan menggunakan Rumus Slovin sehingga diperoleh sampel sebesar 179. Data dikumpulkan menggunakan metode non-tes dengan menggunakan angket yang disebar melalui link google form. Hasil dari penelitian ini menunjukkan bahwa didapatkan kendala pembelajaran daring yang dihadapi oleh guru PAUD berada pada tingkat kategori Sangat Tinggi sebesar $95.53 \%$, dan solusi yang digunakan oleh guru PAUD dalam mengatasi kendala tersebut juga berada pada tingkat kategori Sangat Tinggi sebesar 97.20\%. Dengan demikian dapat disimpulkan bahwa suatu kendala dalam pembelajaran daring diperlukan kemampuan guru dalam mengelola pembelajaran yang dapat dilihat dari pemberian solusi dalam mengatasi kendala pembelajaran daring.
\end{abstract}

\section{A B S T R A C T}

In online learning during the COVID-19 pandemic, teachers are faced with an obstacle to changes in the world of education, especially in early childhood education, so from these obstacles teachers are required to have the ability to manage learning. This study aims to determine and measure the ability of teachers to manage the implementation of online learning during the covid-19 pandemic. This type of research is a descriptive survey with the subject being studied is PAUD teachers. In taking the sample using the Proportional Random Sampling technique by means of statistical calculations, namely by using the Slovin Formula so that a sample of 179 is obtained. Data were collected using a non-test method using a questionnaire distributed via a google form link. The results of this study indicate that the online learning obstacles faced by PAUD teachers are at the Very High category level of $95.53 \%$, and the solutions used by PAUD teachers in overcoming these obstacles are also at the Very High category level of $97.20 \%$. Thus it can be concluded that an obstacle in online learning requires the ability of teachers to manage learning which can be seen from the provision of solutions in overcoming obstacles in online learning.

\section{Pendahuluan}

Pandemi covid-19 yang telah terjadi di seluruh belahan dunia membawa dampak yang cukup serius, salah satunya bagi Indonesia (Asmuni, 2020; Setiawan, 2020). Bukan hanya ekonomi, kesehatan dan keamanan yang terkena dampaknya langsung, namun dunia pendidikan juga terkena dampaknya. Dimana dunia pendidikan di pengaruhi sangat drastis oleh pandemi ini, sehingga guru harus bisa menyesuaikan diri dalam melaksanakan proses pembelajaran (Eliningsih, 2021; Lilawati, 2020). Situasi pandemi ini menjadi tantangan tersendiri bagi kreativitas setiap guru dalam menggunakan teknologi yang

Copyright @ Universitas Pendidikan Ganesha. All rights reserved 
menjadi dasar pengembangan pembelajaran di dunia pendidikan (Purwanto, 2020; Siahaan, 2020). Diharapkan pembelajaran daring menjadi solusi utama untuk melanjutkan kegiatan belajar mengajar (Fikri, 2021; Yulianingsih et al., 2020). Di Indonesia, semua jenjang pendidikan menghentikan kegiatan pembelajarannya secara tatap muka dan berganti menggunakan sistem daring atau belajar jarak jauh (Sari et al., 2020; Wijayanti \& Fauziah, 2020). Hal ini menuntut para pendidik untuk memiliki kemampuan dalam mengelola pembelajaran daring dengan lebih kreatif sehingga proses pembelajaran tetap berlangsung. Tidak terkecuali pendidik PAUD yang juga harus memiliki kemampuan untuk lebih kreatif dalam mengelola pembelajaran secara online (Rizki Tiara, 2020; Nurdin \& Anhusadar, 2020). Pelaksanaan pembelajaran pada PAUD biasanya menggunakan metode yang konvensional dengan bertatap muka yaitu dengan adanya interaksi antara guru dan siswa agar terciptanya suasana yang menyenangkan, namun karena pandemi ini banyak sekali ditemukan kendala oleh guru ataupun siswa itu sendiri (Pudyastuti, 2021; Husna, 2021). Pendidikan saat ini diharapkan mampu membekali setiap peserta didik dengan pengetahuan, keterampilan, serta nilai-nilai dan sikap, dimana proses belajar bukan semata-mata mencerminkan knowledge based tapi mencerminkan pilar pendidikan.

Pada kenyataanya pembelajaran daring memberikan suatu kendala yang dihadapi guru sebagai pendidik dan pengajar (Anugrahana, 2020; Ota et al., 2021; Robandi \& Mudjiran, 2020). Pembelajaran yang semula tatap muka, akibat pandemi tersebut berubah dengan banyak dilakukan secara online. Kendala yang paling sering dihadapi oleh guru adalah salah satunya yaitu kemampuan yang sangat terbatas dalam menggunakan teknologi sehingga dalam penyampaian pembelajaran daring dengan menggunakan media pembelajaran sangatlah monoton (Adhe, 2018; Pakpahan \& Fitriani, 2020). Tidak dapat terbantahkan bahwa peran guru dalam pembelajaran daring memegang posisi yang sangat penting, strategis dan bahkan menjadi kunci untuk mencapai pembelajaran yang bermutu dan efektif. Pembelajaran secara daring juga memanfaatkan perangkat elektronik khususnya internet dalam penyampaian belajar karena pembelajaran daring sepenuhnya bergantung pada akses jaringan internet (Ahmad, 2020; Rigianti, 2020). Berdasarkan hasil pengamatan dan observasi di PAUD Kecamatan Denpasar Utara mendapatkan temuan bahwa pada situasi pandemi ini banyak sekali di temukan kendala dalam memberikan pembelajaran secara daring yaitu keterbatasan teknologi dan koneksi internet. Hal ini dikarenakan masih banyak peserta didik yang memiliki latar belakang ekonomi menengah ke bawah, sehingga tidak mampu memiliki fasilitas pendukung berupa teknologi untuk sarana pembelajaran daring. Namun selain masalah tersebut, terdapat kendala eksternal dalam melaksanakan pembelajaran seperti koneksi internet yang tidak stabil (Harahap, 2021; Yulistia, 2021).

Untuk mewujudkan pembelajaran daring yang efektif diharapkan guru memiliki kemampuan utama dalam pembelajaran, yaitu guru harus menggunakan waktu mengajar secara maksimal, menyampalkan materi dengan metode yang bervariasi, memantau program dan kemajuan melalui penilaian peserta didik, merancang kegiatan belajar bagi peserta didik untuk menerapkan pengalaman belajar, bersedia mengulang materi ketika anak belum memahaminya, menetapkan target belajar untuk setiap anak. permasalahan dalam penerapannya baik bagi guru, peserta didik, orangtua maupun institusi pendidikan (Dewi, 2020; Wahyono et al., 2020). Kemampuan guru dalam mengelola pembelajaran merupakan kesanggupan atau kecakapan para guru dalam menciptakan suasana komunikasi yang edukatif antara guru dan peserta didik yang mencakup keenam aspek perkembangan (aspek kognitif, fisik-motorik, moral-agama, sosial-emosional, bahasa, dan seni), sebagai upaya mempelajari sesuatu berdasarkan perencanaan sampai dengan tahap evaluasi dan tindak lanjut agar tercapai tujuan pembelajaran(Hapsari et al., 2021). Namun untuk mewujudkan hal tersebut diperlukan kesiapan pendidik, kurikulum yang sesuai, ketersediaan sumber belajar serta jaringan yang stabil sehingga komunikasi antar peserta didik dan pendidik dapat efektif. Pada kenyataanya hal tersebut berimbas kepada siswa yang akan sulit dalam memahami materi karena tidak semudah menangkap pembelajaran secara langsung seperti manakala berada di sekolah dan kemampuan guru dalam menyesuaikan diri dengan kondisi yang baru, dimana akan berhubungan dengan teknologi dan membutuhkan perencanaan yang tepat sehingga mampu melaksanakan pembelajaran daring yang efektif dan efisien (Setyosari, 2017; Taradisa, 2020).

Dari pengamatan diatas diketahui bahwa adanya suatu kendala dalam pembelajaran daring akan membuat pembelajaran daring tersebut tidak berjalan dengan efektif karena kendala yang dihadapi bersifat fundamental atau mendasar, maka dari itu kemampuan guru sangat diperlukan untuk mencari solusi dalam pembelajaran daring tersebut supaya bisa berjalan dengan efektif. (Harahap, 2021; Fikri, 2021). Solusi yang dapat digunakan dalam pembelajaran daring tersebut seperti pengadaan pulsa/kuota internet gratis untuk para siswa dan guru, sehingga guru lebih berlatih lagi menggunakan teknologi, dan guru juga dapat mempertimpangkan materi yang diberikan sehingga waktu yang digunakan lebih efisien dan pemanfaatan teknologi yang harus betul-betul dilakukan oleh sekolah untuk menyiasati keadaan yang tak diduga yang dapat mempengaruhi kegiatan belajar mengajar secara daring. Selain itu penguasaan alat 
pembelajaran, materi pembelajaran dan komunikasi yang baik dalam menyampaikan pembelajaran melalui daring juga harus mendukung keberhasilan pembelajaran siswa pada masa pandemi ini (Wahyono, 2020; Sudrajat, 2020). Keadaan ini memaksa guru untuk menyiapkan bahan mengajarnya agar bisa dilaksanakan di rumah masing-masing. Sehingga, dipastikan pelaksanaan kegiatan pembelajaran daring ini memunculkan kendala yang dirasakan oleh guru PAUD sehingga dibutuhkan adanya solusi dari setiap kendala tersebut agar pelaksanaan pembelajaran daring tetap berjalan dengan lancar.

Temuan penelitian sebelumnya mengatakan bahwa solusi yang digunakan adalah guru harus menyiapkan materi pembelajaran semenarik mungkin, seperti penyajian materi dalam slide powerpoint disertai video pembelajaran agar materi lebih hidup dirasakan oleh peserta didik; dalam hal keterbatasan penguasaan IT, guru dapat menggunakan teknologi yang pengoperasiannya lebih sederhana, seperti aplikasi whatsapp (Asmuni, 2020). Temuan lain juga menyatakan siswa bisa melaksanakan pembelajaran daring dengan lebih santai, menyenangkan, fleksibel, efisien, singkat, praktis, cepat, tepat, aman, mudah, hemat waktu, dan hemat tenaga penelitian tersebut dikemukakan oleh (Wahyono, 2020;Jayawardana, 2020). Keterbaruan dari penelitian ini adalah guru dapat mengetahui cara dalam mengelola pembelajaran daring, yang dimana masih banyak memiliki kekurangan baik bagi pengajar maupun siswa. Kekurangan yang paing menonjol adalah belum terbiasa dengan pembelajaran daring karena guru di Indonesia dirasa terlalu gagap dalam mengoperasikan teknologi untuk melakukan pembelajaran daring. Hal tersebut juga dialami oleh peserta didik yang dimana tidak semua peserta didik bisa menggunakannya terutama untuk tingkat PAUD yang masih minim pengetahuan menggunakan media elektronik. Keterbatasan gadget tidak hanya dialami oleh para guru PAUD saja, melainkan juga dialami oleh para orang tua siswa, mengingat pembelajaran online untuk anak-anak PAUD masih harus didampingi oleh orang tua masing-masing. Pembelajaran online di PAUD tanpa didampingi oleh orang tua, hampir mustahil dilakukan, karena pada dasarnya anak-anak PAUD belum mampu menggunakan gadget tersebut dengan sepenuhnya (Taradisa, 2020; Jayawardana, 2020).

Tujuan penelitian ini yaitu lebih melihat kemampuan guru dalam mengelola pembelajaran yang merupakan kesanggupan guru dalam menciptakan suasana komunikasi yang edukatif antara guru dengan peserta didik agar mencapai tujuan pembelajaran. Dalam hal ini, guru perlu berdiskusi dengan kepala sekolah atau lembaga terkait untuk memecahkan masalah atau hambatan yang ditemui dalam proses kegiatan pembelajaran daring sehingga pelaksaanaan pembelajaran daring selanjutnya dapat berjalan dengan lancar dan materi tersampaikan dengan baik ke masing-masing peserta didik. Dari sekian penelitian yang ada dapat diketahui bahwa pembelajaran daring merupakan solusi alternative dalam pelaksanaan pembelajaran di masa pandemi covid-19, namun dapat memunculkan sejumlah permasalahan dalam penerapannya baik bagi guru, peserta didik, orangtua maupun institusi pendidikan.

\section{Metode}

Penelitian ini dilakukan pada seluruh guru PAUD diwilayah Denpasar Utara yang terdiri dari 107 PAUD yang terletak di seluruh desa Pemecutan Kaja, Dauh Puri Kaja, Dangin Puri Kauh, Dangin Puri Kaja, Dangin Puri Kangin, Tonja, Peguyangan, Ubung, Ubung Kaja, Peguyangan Kaja, Peguyangan Kangin. Penelitian ini menggunakan jenis penelitian survei deskritif. Penelitian survei adalah penelitian yang bertujuan untuk mencari informasi faktual yang mendetail dengan gejala yang ada, mengidentifikasi masalah-masalah atau untuk mendapatkan justifikasi keadaan dari kegiatan-kegiatan yang sedang berjalan, dan untuk mengetahui hal-hal yang dilakukan oleh orang-orang yang menjadi sasaran penelitian dalam memecahkan masalah, sebagai bahan penyusunan rencana dan pengambilan keputusan dimasa mendatang. Selain itu penelitian survei juga merupakan metode pengumpulan datanya menggunakan kuesioner dan wawancara sehingga melibatkan subjek atau responden yang banyak, bisa sebagian, bisa pula seluruh populasi (Yatim, 2001; Islamy, 2019) .

Populasi dan sampel merupakan komponen yang sangat diperlukan dalam penelitian. Menentukan sebuah populasi dan sempel harus sesuai dengan langkah-langkah yang telah ditentukan.Populasi adalah keseluruhan dari objek penelitian berupa kumpulan atau merupakan wilayah generalisasi yang terdiri atas objek atau subjek penelitian yang ada dalam wilayah penelitian yang mempunyai kualitas dan karakteristik tertentu yang ditetapkan oleh peneliti untuk dipelajari kemudian ditarik kesimpulan (Kusmanto, 2014; Sugiyono, 2018). Berdasarkan uraian tersebut, maka dapat disimpulkan bahwa populasi merupakan keseluruhan objek yang akan diteliti yang memiliki kuantitas dan karakteristik kriteria tententu yang telah ditetapkan oleh peneliti. Populasi dalam penelitian ini adalah seluruh guru PAUD di Kecamatan Denpasar Utara yang terdiri dari 322 guru PAUD berdasarkan pada Data Pokok Pendidikan (Dapodik) Kementrian Pendidikan dan Kebudayaan Tahun 2021.

Setelah mengetahui populasi yang ada di PAUD wilayah Denpasar Utara selanjutnya adalah menentukan sampel penelitian. Bahwa sampel merupakan bagian dari karakteristik yang dimiliki sebuah 
populasi yang dikemukakan oleh. Dalam penelitian ini, sampel diambil menggunakan teknik "Proportional Random Sampling" yang dimana pengambilan sampel ini dilakukan secara proporsi dilakukan dengan mengambil subyek dari setiap strata atau setiap wilayah ditentukan seimbang dengan banyaknya subyek dalam masing-masing strata atau wilayah. Penentuan sampel dapat dilakukan dengan cara perhitungan statistik yaitu dengan menggunakan Rumus Slovin (Sugiyono, 2017; Arikunto, 2010).

Berdasarkan perhitungan menggunakan rumus Slovin dengan tingkat presisi 5\% maka di peroleh angka n sebesar 179 data sampel. Metode pengumpulan data yang digunakan pada penelitian di PAUD wilayah Denpasar Utara menggunakan metode penelitian non tes. Metode non tes merupakan cara pengumpulan data yang tidak bersifat mengukur dan tidak diperoleh angka-angka sebagai hasil pengukuran, contohnya seperti wawancara, observasi, angket/kuesioner. Kuesioner merupakan cara memperoleh atau mengumpulkan data dengan mengirimkan suatu daftar pertanyaan/pernyataan kepada responden/subjek (Marhaeni, 2012; Agung, 2014). Dalam penelitian ini, angket atau kuesioner akan diberikan kepada guru PAUD di Kecamatan Denpasar Utara melalui link google form untuk mengetahui kendala yang dihadapi serta solusi yang digunakan dalam pelaksanaan pembelajaran daring pada masa covid-19. Kisi-kisi kuesioner ditunjukkan pada Tabel 1.

Tabel 1. Kisi-Kisi Kuesioner Kendala dan Solusi Pembelajaran Daring

\begin{tabular}{|c|c|c|c|}
\hline Aspek & Indikator & No. Soal & Total \\
\hline \multirow[t]{5}{*}{$\begin{array}{l}\text { Kendala guru dalam pembelajaran } \\
\text { daring }\end{array}$} & $\begin{array}{l}\text { Persiapan guru dalam pelaksanaan } \\
\text { pembelajaran daring }\end{array}$ & $1,2,3$ & \\
\hline & $\begin{array}{l}\text { Kelengkapan sarana dan pra-sarana } \\
\text { penunjang }\end{array}$ & $4,5,6$ & \\
\hline & $\begin{array}{l}\text { Kelancaran komunikasi dengan anak dan } \\
\text { orang tua }\end{array}$ & $7,8,9$ & 15 \\
\hline & Penentuan metode pembelajaran & $10,11,12$ & \\
\hline & $\begin{array}{l}\text { Pemilihan materi pembelajaran yang tepat } \\
\text { penentuan evaluasi pembelajaran daring }\end{array}$ & $\begin{array}{c}13,14 \\
15\end{array}$ & \\
\hline \multirow[t]{4}{*}{$\begin{array}{l}\text { Solusi dalam mengatasi kendala } \\
\text { pembelajaran daring }\end{array}$} & Penyiapan pembelajaran yang tepat & $\begin{array}{c}16,17 \\
18,19,20\end{array}$ & \\
\hline & $\begin{array}{l}\text { Kolaborasi tindakan bimbingan antara } \\
\text { guru dengan guru dan guru dengan orang } \\
\text { tua }\end{array}$ & $\begin{array}{l}21,22 \\
23 \\
24,25\end{array}$ & 15 \\
\hline & $\begin{array}{l}\text { Kelengkapan sarana dan pra-sarana } \\
\text { penunjang pemelajaran }\end{array}$ & $\begin{array}{l}26,27 \\
28,29\end{array}$ & \\
\hline & Evaluasi kegiatan & 30 & \\
\hline \multicolumn{3}{|c|}{ Total Butir Soal } & 30 \\
\hline
\end{tabular}

Untuk mendapatkan data yang baik perlu dilakukanya beberapa uji instrumen, uji yang digunakan dalam penelitian ini yaitu uji validitas konstruk yang diuji oleh judges untuk mengetahui kelayakan instrument bedasarkan kesesuaian antara grand theory, kisi-kisi terhadap butir pernyataan. Serta dengan uji validitas butir yang memperoleh data bahwa 30 butir memiliki nilai pearson correlation $>0,146$ (nilai $r$ tabel untuk $\mathrm{N}=179$ ) sehingga dapat disimpulkan bahwa semua butir valid. Data yang telah diperoleh kemudian di analisa, dengan menggunakan pengantar statistika deksriptif yang diperoleh dari hasil data kuantitatif.

\section{Hasil dan Pembahasan}

Berdasarkan data yang telah dikumpulkan dengan memberikan angket kepada guru PAUD wilayah Denpasar Utara diperoleh dari jawaban kuesioner dengan total 30 butir pernyataan yang berkaitan dengan kendala dan solusi pembelajaran daring. Setiap aspek masing-masing memiliki 15 pernyataan yang saling berhubungan. Untuk kendala pembelajaran daring skor tertinggi sebesar 60, skor terendah sebesar 42, rata-rata sebesar 53.23, median sebesar 53, dan modus sebesar 53. Sedangkan pada solusi pembelajaran daring memiliki skor tertinggi sebesar 60, skor terendah sebesar 43 , rata-rata sebesar 54.04, mediasn sebesar 54, dan modus sebesar 54. Data yang diperoleh dalam penelitian ini berasal dari jawaban kuesioner dengan total 30 butir pernyataan yang berkaitan dengan kendala dan solusi pembelajaran daring. Sesuai rekapitulasi hasil perhitungan, maka selanjutnya dilakukan analisis data terkait persepsi terhadap kendala dalam pembelajaran daring. 
Data responden pada aspek kendala pembelajaran daring adalah data primer yang diperoleh dari skor total kuesioner. Pada aspek kendala pembelajaran daring terdiri dari 15 butir pernyataan yang sudah diisi oleh respoden. Dinyatakan bahwa data kendala yang dihadapi guru dalam pelaksanaan pembelajaran daring paling banyak berada pada rentang skor 53-55 dengan presentase skor aspek kendala pembelajaran daring paling banyak adalah sebanyak $55.87 \%$ dari jumlah sampel sebanyak 179 orang. Perolehan skor kendala pembelajaran daring dikategorikan menggunakan distribusi frekuensi kecenderungan aspek kendala yang dihadapi oleh guru dalam pelaksanaan pembelajaran daring yang dapat diidentifikasikan menggunakan nilai mean dan standar deviasi. Mengenai pengkategorian distribusi frekuensi aspek kendala yang dihadapi oleh guru dalam pelaksanaan pembelajaran daring dapat dicari dengan menentukan batas interval setiap kategori. Kategori ditentukan dengan skala angka pada interval. Skala angka didapat dari hasil perkalian standar deviasi dengan koefisien tertentu. Koefisien tersebut adalah 1.5 dan 0.5. Selanjutnya dilakukan penjumlahan/pengurangan dengan mean sesaui dengan kategori pada setiap kelas interval, sehingga didapatkan frekuensi yang paling banyak terdapat pada interval 48 ke atas dengan frekuensi absolut 171 dan dengan presentase $95.53 \%$. Persentase nilai setiap butir pernyataan aspek kendala dalam pembelajaran daring, dapat diidentifikasi bahwa persentase paling besar dalam kendala yang dihadapi guru-guru PAUD di Kecamatan Denpasar adalah kendala dalam penyusunan rencana pembelajaran daring dengan persentase sebesar $93.85 \%$.

Selanjutnya dilakukan analisis data untuk solusi dalam pembelajaran daring, dari data aspek solusi pembelajaran daring inilah dapat diketahui kemampuan guru dalam mengelola pembelajaran sehingga adanya kendala pembelajaran daring tidak menghalangi guru untuk memberikan pendidikan pada peserta didik untuk mencapai tujuan pembelajaran. Dinyatakan bahwa data solusi yang digunakan guru dalam mengatasi kendala pelaksanaan pembelajaran daring paling banyak berada pada rentang skor 53-54. Dengan dijabarkan lebih rinci menggunakan grafik atau diagram lingkaran dengan presentase skor aspek solusi pembelajaran daring paling banyak adalah sebanyak $34.64 \%$ dari jumlah sampel sebanyak 179 orang. Perolehan skor solusi pembelajaran daring dikategorikan menggunakan distribusi frekuensi kecenderungan aspek solusi yang digunakan oleh guru dalam mengatasi kendala dalam pelaksanaan pembelajaran daring yang dapat diidentifikasikan menggunakan nilai mean dan standar deviasi. mengenai pengkategorian distribusi frekuensi aspek solusi yang digunakan oleh guru dalam mengatasi kendala pelaksanaan pembelajaran daring dapat dicari dengan menentukan batas interval setiap kategori. Kategori ditentukan dengan skala angka pada interval. Skala angka didapat dari hasil perkalian standar deviasi dengan koefisien tertentu. Koefisien tersebut adalah 1.5 dan 0.5. Selanjutnya dilakukan penjumlahan/pengurangan dengan mean sesaui dengan kategori pada setiap kelas interval. Distribusi frekuensi kecenderungan aspek solusi dalam pembelajaran daring di Kecamatan Denpasar Utara, maka didapatkan frekuensi yang paling banyak terdapat pada interval 48 ke atas dengan frekuensi absolut 174 dan dengan presentase $97.20 \%$. Serta dari data tersebut diketahui bahwa kemampuan guru dalam mengelola pembelajaran daring pada masa pandemi covid-19 masuk ke dalam kategori Sangat Tinggi.

Persentase nilai setiap butir pernyataan pada aspek solusi pembelajaran daring, teridentifikasi bahwa dua pernyataan solusi sama-sama memiliki persentase paling besar yaitu 93.02\%. Pernyataan solusi yang pertama yaitu mengadakan kuota gratis untuk mengatasi kendala dalam keterbatasan biaya untuk membeli kuota internet. Sedangkan pernyataan solusi yang kedua yaitu mengajak orang tua untuk saling terbuka tentang perkembangan anak sehingga komunikasi berjalan dua arah untuk kendala tentang orang tua yang tidak memberikan informasi yang sebenarnya terjadi tentang kegiatan dan keadaan anak selama belajar di rumah. Hasil dari penelitian mengenai identifikasi kendala dan solusi dalam pelaksanaan pembelajaran daring pada masa pandemi covid-19 di Kecamatan Denpasar Utara yang dibagi menjadi 2 aspek penelitian yaitu aspek kendala pembelajaran daring dan aspek solusi pembelajaran daring telah memberikan jawaban atas masalah dalam penelitian ini. Berdasarkan hasil perhitungan tersebut, maka didapatkan kendala pembelajaran daring yang dihadapi oleh guru PAUD berada pada tingkat kategori Sangat Tinggi, Kendala dalam pelaksanaan pembelajaran daring diantaranya yaitu kendala dalam menyusun rencana pembelajaran daring memiliki persentase sebesar 93.85\%, kendala dalam memperoleh pedoman pembelajaran daring memiliki persentase sebesar $93.30 \%$, kendala dalam memiliki alat mengajar seperti gadget/gawai/laptop memiliki persentase sebesar $60.47 \%$, kendala dalam menggunakan media untuk mengajar daring memiliki persentase sebesar 92.73\%, kendala karena keterbatasan biaya untuk membeli kuota internet memiliki persentase sebesar 90.50\%, terkendala jaringan/akses internet memiliki persentase sebesar $85.61 \%$, sulit berkomunikasi dengan orangtua karena terkendala alat komunikasi memiliki persentase sebesar $91.34 \%$, orang tua tidak memberikan informasi yang sebenarnya terjadi tentang kegiatan anak di rumah memiliki persentase sebesar 91.20\%, kesulitan dalam membangkitkan semangat belajar anak memiliki persentase sebesar 89.11\%, bingung menentukan metode mengajar yang tepat \& relvan memiliki persentase sebesar 92.32\%. Sehingga dapat disimpulkan bahwa kendala yang paling banyak dialami oleh guru-guru PAUD dalam pelaksanaan 
pembelajaran daring ini adalah kendala dalam menyusun rencana pembelajaran daring dengan persentase sebesar $93.85 \%$.

Sedangkan solusi yang digunakan oleh guru PAUD dalam mengatasi kendala tersebut juga berada pada tingkat kategori Sangat Tinggi. Maka, solusi yang dijadikan cara penyelesaian masalah atau kendala dalam pelaksanaan pembelajaran daring diantaranya membuat rancangan pembelajaran yang sederhana dengan memaksimalkan sumber daya yang ada dalam mengatasi kendala menyusun rencana pembelajaran memiliki persentase sebesar 89.80\%, menyederhanakan kegiatan agar sesuai dengan peraturan yang ditetapkan oleh Kemdikbud pada masa pandemi dalam mengatasi kendala memperoleh pedoman pembelajaran daring untuk PAUD memiliki persentase sebesar $89.39 \%$, mempersilahkan orang tua datang ke sekolah seminggu sekali untuk mengumpulkan dan mengambil tugas anak dalam mengatasi kendala untuk memiliki alat mengajar seperti gadget/gawai memiliki persentase sebesar 89.25\%, mengikuti pelatihan online seperti Webinar melalui Zoom/Google Meet dalam mengatasi kendala menggunakan media untuk mengajar daring memiliki persentase sebesar $81.15 \%$, megadakan kuota gratis menggunakan dana BOS/BOP dalam mengatasi kendala keterbatasan biaya untuk membeli kuota internet memiliki persentase sebesar 93.02\%, memberikan tenggang waktu yang cukup dalam mengirimkan tugas agar tidak tergesa-gesa dalam mengatasi kendala jaringan / akses internet memiliki persentase sebesar 90.64\%, guru melakukan kunjungan langsung dengan orang tua dalam mengatasi kendala Sulit berkomunikasi dengan orangtua memiliki persentase sebesar $87.71 \%$, mengajak orang tua untuk saling terbuka tentang perkembangan anak sehingga komunikasi berjalan dua arah dalam mengatasi kendala Orang tua yang tidak memberikan informasi yang sebenarnya terjadi tentang kegiatan anak di rumah memiliki persentase sebesar 93.02\%, rutin memberikan hadiah atau reward pada hasil kegiatan anak dalam mengatasi kendala membangkitkan semangat belajar anak memiliki persentase sebesar 89.25\%, saling bertukar infromasi dengan sesama guru mengenai pemilihan metode mengajar dalam mengatasi kendala kesulitan menentukan metode mengajar yang tepat dan relvan memiliki persentase sebesar $90.50 \%$. Maka, dapat disimpulkan bahwa solusi yang paling sering digunakan adalah solusi mengadakan kuota gratis untuk mengatasi kendala dalam keterbatasan biaya untuk membeli kuota internet dan solusi mengajak orang tua untuk saling terbuka tentang perkembangan anak sehingga komunikasi berjalan dua arah untuk kendala tentang orang tua yang tidak memberikan informasi yang sebenarnya terjadi tentang kegiatan dan keadaan anak selama belajar di rumah yang sama-sama memiliki persentase sebsar $93.02 \%$.

Berdasarkan hasil perhitungan diatas menandakan bahwa pada masa pandemi covid-19 banyak ditemukan kendala dalam pembelajaran daring yaitu ketidakmampuan guru dalam beradaptasi dalam pelaksanaan pembelajaran daring seperti masih menggunakan gaya mengajar yang biasa dengan media pembelajaran daring yang baru dan tidak berusaha mengembangkan kemampuan pedagogi untuk mampu menggunakan teknologi. Pelaksanaan pembelajaran daring mengakibatkan peran guru dalam proses pembelajaran tidak terlaksana secara maksimal. Selain guru, orang tua juga mengalami kendala yaitu kurangnya pemahaman materi oleh orang tua dan sarana prasarana yang kurang memadai. Meskipun demikian pembelajaran daring harus tetap dilaksanakan (Husna, 2021; Robandi \& Mudjiran, 2020). Kendala mengajar yang dialami guru PAUD pada masa pandemi covid 19 yang mencakup empat indikator yaitu indikator kendala komunikasi, indikator kendala metode pembelajaran, indikator kendala materi, dan indikator kendala biaya serta penggunaan teknologi (Agustin, 2020). Pelaksanaan pembelajaran daring memiliki tantangan/kendala, baik dari aspek sumber daya manusia, sarana-prasarana, dan teknis implementasi (Wahyono, 2020). Keterbatasan kuota internet atau paket internet yang menjadi penghubung dalam pembelajaran daring juga ikut serta dalam suatu kendala. Hal tersebut mengakibatkan keikutsertaan peserta didik dalam pembelajaran juga tidak mencapai $100 \%$ dalam pembelajaran daring, karena beberapa peserta didik bahkan ada yang tidak mengikuti pembelajaran sama sekali dari awal hingga akhir, sehingga guru merasa bingung dalam proses penilaian peserta didik tersebut. Terutama penerapan pembelajran daring di daerah pelosok dengan teknologi dan jaringan internet yang masih terbatas (Putria, 2020; Wahyono, 2020). Namun ada beberapa penelitian mengatakan bahwa pembelajaran daring memberikan metode pembelajaran yang efektif, seperti berlatih dengan adanya kegiatan belajar mandiri (Adhe, 2018).

Kemampuan Guru dalam memberi solusi menjadi penentu utama keberhasilan proses pembelajaran, yang dimana guru harus berusaha sedemikian mungkin agar kegiatan pembelajaran daring yang dilakukan berhasil. Maka dari itu, seorang guru perlu mengetahui dan dapat menerapkan beberapa prinsip mengajar agar dapat melaksanakan tugasnya secara profesional. Diantaranya, guru harus dapat membangkitkan perhatian peserta didik pada materi pelajaran yang diberikan serta dapat menggunakan berbagai media dan sumber belajar yang bervariasi. Guru sebagai tenaga pendidik juga harus memiliki kemampuan teknologi dengan model pembelajaran jarak jauh atau daring agar materi pelajaran tersampaikan dengan baik, seperti penggunaan platform Whatsapp sehingga tidak ada lagi kendala yang 
dialami oleh guru (Basar, 2021; Husna, 2021). Pelaksanaan pembelajaran daring melalui media group WhatsApp membuat siswa merasa lebif efektif dan nyaman dalam pembelajaran daring (Setyosari, 2017; Nengrum, 2021).

Kelebihan dari penelitian ini adalah untuk menganalisis kemampuan guru PAUD dalam mengelelola pembelajaran pada masa pandemi covid-19 di Kecamatan Denpasar Utara. Selain itu membahas mengenai kendala yang dihadapi oleh guru-guru serta solusi yang digunakan untuk mengatasi kendala pembelajaran sehingga guru-guru PAUD dapat mengelola pembelajaran daring dengan baik, setiap permasalahan yang dihadapi bisa diselesaikan dengan menghadirkan beragam solusi dari para guru sehingga pembelajaran di masa pandemi covid-19 tetap berlangsung, yang penting anak tetap belajar dan terus belajar meskipun belajar jarak jauh. Penelitian ini dapat memberikan kontribusi kepada guru, orang tua dan murid agar dapat betul-betul siap dalam pelaksanaan pembelajaran daring. Dan guru dapat mempersiapkan segala sesuatu yang dirasa dapat menunjang kegiatan pembelajaran daring dapat terlaksana sehingga peserta didik tetap mendapatkan haknya dalam pendidikan. Kajian ini dapat dijadikan sebagai bahan referensi bagi guru dan peserta didik dalam melaksanakan pembelajaran daring dan bagi orang tua dalam mendukung pembelajaran daring, serta pembelajaran daring di saat pandemi covid-19 hendaknya guru mencari solusi yang inovatif dan berpikir secara kreatif agar proses pembelajaran di sekolah tetap berjalan walaupun tidak dapat bertatap muka langsung.

\section{Simpulan}

Pelaksanaan pembelajaran daring yang merupakan pembelajaran jarak jauh di masa pandemi covid-19 memiliki beragam problematika yang dialami guru, peserta didik, dan orangtua. Sehingga perubahan pada cara pelaksanaan pembelajaran yang terjadi mengakibatkan inovasi pembelajaran daring yang selama ini dilakukan oleh lembaga pendidikan, termasuk pendidikan anak usia dini. Guru harus memiliki kemampuan untuk siap dalam melaksanakan pembelajaran daring, kesiapan guru dalam pembelajaran daring ini akan mempertahankan tujuan dan kualitas pembelajaran. Beragam permasalahan tersebut dapat diatasi dengan meningkatkan kompetensi penguasaan IT.

\section{Daftar Rujukan}

Adhe, K. R. (2018). Pengembangan Media Pembelajaran Daring Matakuliah Kajian PAUD di Jurusan PG PAUD Fakultas Ilmu Pendidikan Universitas Negeri Surabaya. Journal of Early Childhood Care and Education, 1(1), 26-31. https://doi.org/10.26555/jecce.v1i1.3.

Agung, A. A. G. (2014). Metodologi Penelitian Pendidikan. Aditya Media Publishing.

Agustin, M. (2020). Tipikal Kendala Guru PAUD dalam Mengajar pada Masa Pandemi Covid 19 dan Implikasinya. Jurnal Obsesi : Jurnal Pendidikan Anak Usia Dini, 5(1), 334-345. https://doi.org/10.31004/obsesi.v5i1.598.

Ahmad. (2020). Peningkatan Kompetensi Pedagogik Guru dalam Pembelajaran Jarak Jauh Melalui Pendampingan Sistem Daring, Luring, atau Kombinasi pada Masa New Normal Covid 19. Jurnal Paedagogy, 7(4), 258-264. https://doi.org/10.33394/jp.v7i4.2803.

Anugrahana, A. (2020). Hambatan, Solusi dan Harapan : Pembelajaran Daring Selama Masa Pandemi Covid-19 Oleh Guru Sekolah Dasar. Scholaria: Jurnal Pendidikan Dan Kebudayaan, 10(3), 282-289. https://ejournal.uksw.edu/scholaria/article/view/4033.

Arikunto, S. (2010). Prosedur penelitian : suatu pendekatan praktik. Rineka Cipta.

Asmuni, A. (2020). Problematika Pembelajaran Daring di Masa Pandemi Covid-19 dan Solusi Pemecahannya. Jurnal Paedagogy, 7(4), 281. https://doi.org/10.33394/jp.v7i4.2941.

Basar, A. M. (2021). Problematika Pembelajaran Jarak Jauh Pada Masa Pandemi Covid-19. Edunesia : Jurnal Ilmiah Pendidikan, 2(1), 208-218. https://doi.org/10.51276/edu.v2i1.112.

Dewi, W. A. F. (2020). Dampak COVID-19 Terhadap Implementasi Pembelajaran Daring Di Sekolah Dasar. Jurnal Ilmu Pendidikan, 2(1), 55-61. https://edukatif.org/index.php/edukatif/index.

Eliningsih. (2021). Peningkatan Kemampuan Guru Dalam Manajemen Pengelolaan Kelas Di Masa Pandemi Covid-19 Melalui Supervisi Klinis. Journal Nuansa Akademik, 6(1), 25-36. https://doi.org 10.47200/jnajpm.v6i1.690.

Fikri, M. (2021). Kendala Dalam Pembelajaran Jarak Jauh di Masa Pandemi Covid-19: Sebuah Kajian Kritis. Jurnal Education and Development Institut Pendidikan Tapanuli Selatan, 9(1), 145-148.

Hapsari, F., Desnaranti, L., \& Wahyuni, S. (2021). Peran Guru dalam Memotivasi Belajar Siswa selama Kegiatan Pembelajaran Jarak Jauh. Research and Development Journal of Education, 7(1), 193. https://doi.org/10.30998/rdje.v7i1.9254.

Harahap, S. A. (2021). Problematika Pembelajaran Daring dan Luring Anak Usia Dini bagi Guru dan Orang 
tua di Masa Pandemi Covid 19. Jurnal Obsesi : Jurnal Pendidikan Anak Usia Dini, 5(2), 1825-1836. https://doi.org/10.31004/obsesi.v5i2.1013.

Husna, R. (2021). Identifikasi Kesulitan Guru Matematika Dalam Pelaksanaan Pembelajaran Daring di Masa Pandemi Covid-19. 7(2), 428-436. https://doi.org/10.33394/jk.v7i2.333.

Islamy, I. (2019). Penelitian Survei dalam Pembelajaran \& Pengajaran Bahasa Inggris. Pasca Sarjana Pendidikan Bahasa Inggris, August, 1-9.

Jayawardana, H. B. . (2020). Identifikasi Kesulitan Guru Paud Di Masa Pandemi Covid-19 Dan Solusinya. PAUDIA: Jurnal Penelitian Dalam Bidang Pendidikan Anak Usia Dini, 9(2), 40-50. https://doi.org/10.26877/paudia.v9i2.6647.

Kusmanto, H. (2014). Pengaruh Berpikir Kristis Terhadap Kemampuan Siswa Dalam Memecahkan Masalah Matematika (Studi Kasus Di Kelas VII SMP Wahid Hasyim Moga). Eduma: Mathematics Education Learning and Teaching, 3(1). https://doi.org/10.24235/eduma.v3i1.6.

Lilawati, A. (2020). Peran Orang Tua dalam Mendukung Kegiatan Pembelajaran di Rumah pada Masa Pandemi. Jurnal Obsesi: Jurnal Pendidikan Anak Usia Dini, 5(1), 549. https://doi.org/10.31004/obsesi.v5i1.630.

Marhaeni. (2012). Pengantar Evaluasi Pendidikan. Universitas Pendidikan Ganesha.

Nengrum, T. A. (2021). Kelebihan dan Kekurangan Pembelajaran Luring dan Daring dalam Pencapaian Kompetensi Dasar Kurikulum Bahasa Arab di Madrasah Ibtidaiyah 2 Kabupaten Gorontalo. Jurnal Pendidikan, 30(1), 1-12.

Nurdin, N., \& Anhusadar, L. (2020). Efektivitas Pembelajaran Online Pendidik PAUD di Tengah Pandemi Covid 19. Jurnal Obsesi : Jurnal Pendidikan Anak Usia Dini, 5(1), 686-697. https://doi.org/10.31004/obsesi.v5i1.699.

Ota, M. K., Djou, A. M. G., \& Numbah, F. F. (2021). Problematika Pembelajaran Daring Siswa Kelas Vii Smpn. Jurnal Pengabdian Masyarakat, 2(1), 74-81. https://doi.org/10.37478/mahajana.v2i1.769.

Pakpahan, R., \& Fitriani, Y. (2020). Analisa Pemafaatan Teknologi Informasi Dalam Pemeblajaran Jarak Jauh Di Tengah Pandemi Virus Corona Covid-19. JISAMAR (Journal of Information System, Applied, Management, Accounting and Researh), 4(2), 30-36. http://journal.stmikjayakarta.ac.id/index.php/jisamar/article/view/181.

Pudyastuti, A. T. (2021). Efektivitas Pembelajaran E-Learning pada Guru PAUD Selama Pandemic Covid19. Jurnal Obsesi: Jurnal Pendidikan Anak Usia Dini, 5(2), 1667-1675. https://doi.org/10.31004/obsesi.v5i2.873.

Purwanto, A. (2020). Studi eksplorasi Dampak WFH Terhadap Kinerja Guru. Journal of Education, Psychology and Counseling, 2(1), 92-100.

Putria, H. (2020). Analisis Proses Pembelajaran Dalam Jaringan (DARING) Masa Pandemi COVID-19 pada Guru Sekolah Dasar. Jurnal BASICEDU, 4(4), 861-872. https://doi.org/10.31004/basicedu.v4i4.460.

Rigianti, H. (2020). Kendala Pembelajaran Daring Guru Sekolah Dasar Di Kabupaten Banjarnegara. Jurnal Pendidikan Dan Pembelajaran Ke SD-An, 7(2), 1-9. https://doi.org/10.31316/esjurnal.v7i2.768.

Rizki Tiara, D. (2020). Mengukur Kesiapan Guru Sebagai Dasar Pembelajaran Daring Di Lembaga PAUD. Jurnal Golden Age, 4(02), 362-368. https://doi.org/10.29408/jga.v4i02.2624.

Robandi, D., \& Mudjiran, M. (2020). Dampak Pembelajaran Dari Masa Pandemi Covid-19 terhadap Motivasi Belajar Siswa SMP di Kota Bukittinggi. Jurnal Pendidikan Tambusai, 4(3), 3498-3502. https://doi.org/10.31004/jptam.v4i3.878.

Sari, W., Rifki, A. M., \& Karmila, M. (2020). Pembelajaran Jarak Jauh Pada Masa Darurat Covid 19. Jurnal MAPPESONA, 1, 12.

Setiawan, W. \& D. Y. (2020). Dampak Pandemi COVID-19 Terhadap Kegiatan Pembelajaran Online di STMIK Komputama Majenang. Teknologi Dan Bisnis, 2(2), 16-25. https://doi.org/10.37087/jtb.v2i2.21.

Setyosari, P. (2017). Menciptakan Pembelajaran yang Efektif dan Berkualitas. JINOTEP, 1(1), 20-30. https://doi.org/10.17977/um031v1i12014p020.

Siahaan, M. (2020). Dampak Pandemi Covid-19 Terhadap Dunia Pendidikan. Jurnal Kajian Ilmiah, 1(1), 73-80. https://doi.org/10.31599/jki.v1i1.265.

Sudrajat, J. (2020). Kompetensi Guru Di Masa Pandemi Covid-19. Jurnal Riset Ekonomi Dan Bisnis, 13(2), 100. https://doi.org/10.26623/jreb.v13i2.2434

Sugiyono. (2017). Statistika untuk Penelitian. Alfabeta.

Sugiyono. (2018). Statistika untuk Penelitian. Alfabeta.

Taradisa, N. (2020). Kendala Yang Dihadapi Guru Mengajar Daring Pada Masa Pandemi COvid 19 MIN 5 Banda Aceh. UIN Ar-Raniry Banda Aceh, 1(1), 23-33.

Wahyono, P. (2020). Guru profesional di masa pandemi COVID-19: Review implementasi, tantangan, dan solusi pembelajaran daring. Jurnal Pendidikan Profesi Guru, 1(1), 51-65. 
Wahyono, P., Husamah, H., \& Budi, A. S. (2020). Guru profesional di masa pandemi COVID-19: Review implementasi, tantangan, dan solusi pembelajaran daring. Jurnal Pendidikan Profesi Guru, 1(1), 5165. https://doi.org/10.22219/jppg.v1i1.12462.

Wijayanti, R. M., \& Fauziah, P. Y. (2020). Perspektif dan Peran Orangtua dalam Program PJJ Masa Pandemi Covid-19 di PAUD. Jurnal Obsesi: Jurnal Pendidikan Anak Usia Dini, 5(2), 1304-1312. https://doi.org/10.31004/obsesi.v5i2.768.

Yatim, R. (2001). Metodologi Penelitian Pendidikan. SIC.

Yulianingsih, W., Suhanadji, S., Nugroho, R., \& Mustakim, M. (2020). Keterlibatan Orangtua dalam Pendampingan Belajar Anak selama Masa Pandemi Covid-19. Jurnal Obsesi : Jurnal Pendidikan Anak Usia Dini, 5(2), 1138-1150. https://doi.org/10.31004/obsesi.v5i2.740

Yulistia, A. (2021). LMS VCLASS Unila: Solusi untuk Meningkatkan Kemandirian Belajar dalam Pembelajaran Daring di Masa Pandemi. Institutional Respository, 1(1), 153-159. 